\title{
Business Model Canvas For Indonesian Aerospace's CN235 Aircraft
}

\author{
Mohamad Ikhsan Nurulloh ${ }^{1 *}$, Luhut Simbolon ${ }^{2}$, George Royke Deksino ${ }^{3}$ \\ 1,2,3 Defense Industry Study Program, Faculty of Defense Technology, \\ Republic of Indonesia Defense University \\ *Corresponding Author: \\ Email: ikhsannur1996@gmail.com
}

\begin{abstract}
.
This research aims to conduct a qualitative assessment of the business model canvas on the CN235 Aircraft manufactured by Indonesian Aerospace (IAe). This research is a descriptive qualitative study of the business model canvas and then uses SWOT analysis to evaluate each item. Interviews and documentation are the methods for data collection. This study shows that IAe's market segmentation is domestic and global markets. The company uses a digital system and delivers services that exceed the expectations of its customers. IAe is the only domestic manufacturing industry that can manufacture aircraft. The company makes money by selling planes and providing maintenance services. Building and keeping strong connections with business partners is critical in collaboration. The most common expenditures incurred by IAe are fixed and variable expenses. The study findings are supposed to reveal the IAe's strengths, weaknesses, opportunities, internal and external challenges, and innovation strategy.
\end{abstract}

Keywords: business model, canvas, SWOT analysis

\section{INTRODUCTION}

PT Dirgantara Indonesia (Persero) or Indonesian Aerospace (IAe) is the first aircraft industry in Indonesia and Southeast Asia. This company is an Indonesian stateowned enterprise. After a long period of deficits, IAe made a net profit of approximately $\$ 10.6$ million in 2019. The worldwide defense industry's state in 2020 changed dramatically due to the Covid-19 epidemic. The Covid-19 outbreak has impacted the local defense sector, which is struggling to sustain manufacturing production in the face of interruptions in global supply networks and decreasing productivity. The Covid-19 pandemic encourages IAe to preserve and improve its business processes. A viable business process is required to gain a competitive advantage with a high economic value.CN235 aircraft is one of the biggest IAe's markets. IAe manufactured $69 \mathrm{CN} 235$ aircraft out of a total of 285 units in the globe, contributing for $25 \%$ of global CN235 aircraft market share [1]. The aircraft production capabilities of IAE have been confirmed. IAe should be competitive internationally due to its large market and already qualified manufacturing capabilities.The aerospace industry is a strategic industrial sector with solid development potential and a worldwide market focus [2]. 
The capacity to produce goods or services that meet international standards while growing long-term income is industrial competitiveness. Business players must change and implement appropriate and effective business strategies to preserve market share and boost competitiveness to deal with this situation. Before developing a business strategy, companies should understand how a firm or organization produces, delivers, and describes value using a business model framework.A business strategy is an integrated and coordinated set of goals and activities to capitalize on critical competencies and gain a competitive advantage. Establishing a business model is one business technique that may be applied. A business model is a model that explains how firms create and produce value. Companies can orient an established business model by identifying markets, rivals, and consumers and developing a competitive advantage [3].Business Model Canvas (BMC) is one of the business models that create, explain, and conclude business components into a single strategy. It makes business mapping more manageable and efficient.

The business model canvas has nine essential elements: customer segments, value propositions, channels, customer relationships, revenue streams, key resources, key activities, key partnerships, and cost structures. These elements can transform complex business concepts into simple and easy to understand [4]. The business model canvas is a tool that may enable companies to adjust and develop new business models rapidly. It displays how to focus on economics and business procedures and generate value [5]. Business actors may use it to create alternative business strategies. The SWOT analysis objectively identifies the various factors to develop a business strategy. This approach is based upon the principle of maximizing strengths and opportunities. However, it may also be used to minimize weaknesses and threats. SWOT analysis is required for each section of the canvas to design a better business model canvas [6]. SWOT analysis needs before developing a strategy to address current business [7]. While the SWOT approach uses in the business formulation process, it might suggest improving and refining the present business model canvas. It may be formalized as a management implication for business development to boost competitiveness.

\section{METHODS}

The descriptive technique was employed in this study, with a case study methodology. The CN235 Aircraft produced by Indonesian Aerospace (IAe) was the subject of this study's case study. This research conducts a qualitative assessment of the business model canvas. Interviews and documentation are used to obtain data. This study described the nine aspects of the canvas business model and evaluated using descriptive-analytical approaches and SWOT analysis. 


\section{RESULT AND DISCUSSION}

\section{Business Model Canvas}

Based on the analysis of the nine aspects of the canvas business model, the following describes the canvas business model of the CN235 aircraft produced by IAe.

Table 1. Business Model Canvas for Indonesian Aerospace's CN235 Aircraft

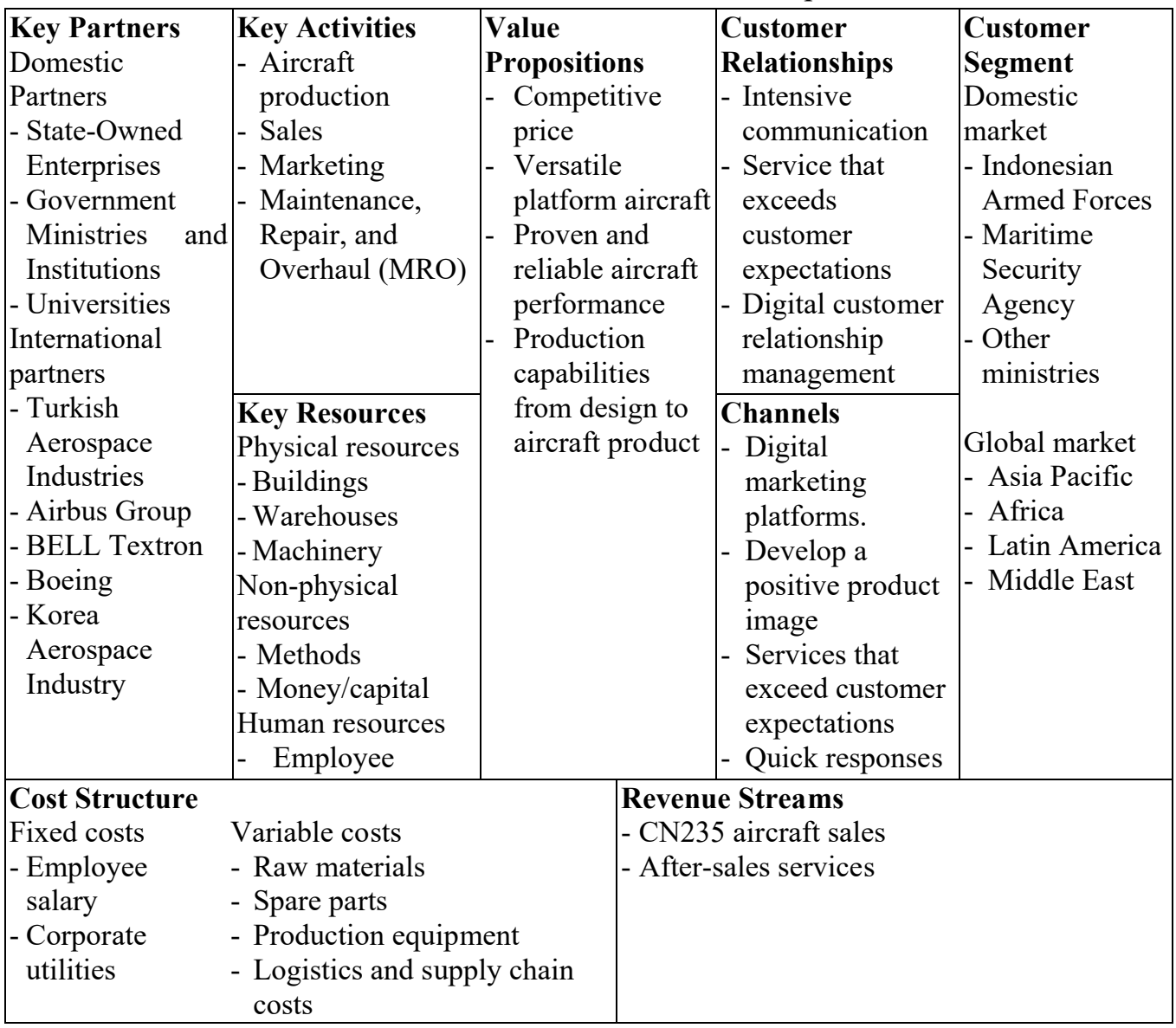

The business canvas model serves as a connection in creating value for consumers and businesses, assisting firms in detecting external and internal surroundings and generating a proportion of value from opportunity investment. The following are the current results of the identification of the nine business canvas model blocks on Indonesian Aerospace:

\section{a. Customer Segment}

The CN235 aircraft customer sector is a specific category with a niche market. Demand for aircraft for military purposes is enormous, and the possibility of selling the CN235 aircraft remains widespread. Indonesian Armed Forces, Maritime Security Agency, and other relevant ministries or entities are domestic market targets. Meanwhile, Asia Pacific, Africa, Latin America, and the Middle East are global 
markets for the CN235 aircraft. Other nations that have purchased CN235 aircraft from Airbus are prospective after-sales service markets.

\section{b. Value Proposition}

The first value proposition is the product proposition, which is the additional value of the CN235 aircraft, including the versatile platform aircraft with multipurpose and quick settings change. The machine is $15 \%$ more fuel-efficient than previous machines of the same capabilities, and it has a ramp door for cargo and troop/paratroop access. The $\mathrm{CN} 235$ aircraft has a competitive price compared to competitors in its class, proven and reliable aircraft performance. The CN235 aircraft is a medium-sized turboprop aircraft at a more affordable price and is sufficient for the operation and matching customer budget. IAe only manufacturer that produces new CN235 aircraft. The company handles the quality, pricing, and delivery of the CN235 aircraft. The second value proposition is that IAe is the only company with aircraft production capabilities ranging from design to raw materials to aircraft. The company has maintenance capabilities for all aircraft delivered and several aircraft manufacturers with IAe.

\section{c. Channels}

Channels are a way for a company to create and establish relationships with customers to provide value propositions. The company enhances its marketing and sales capabilities by providing training to support marketing and sales operations and establishing networks with prospective customers. The company reduces marketing and sales costs through digital marketing and digital platforms. The most significant aspects of IAe are marketing and sales. Marketing and sales will begin manufacturing or service contracts. After the company and the client had engaged in a contract, other activities were carried out. Following the signing of the agreement, the company will carry out production planning through operating activities supported by other aspects of the business canvas model.The company develops a positive product image and raises awareness of new customers for the products to be delivered. The company provides services that exceed customer expectations and quick responses. IAe's product is a niche market, and there is still a high need for military aircraft.

\section{d. Customer Relationship}

Customer relationship function is to acquire new consumers and keep existing ones. The company communicates regularly with consumers and potential and gathers feedback to improve capabilities. The company develops a digital platform for aftersales support in the form of customer relationship management, allowing customers to interact with the helpdesk company in real-time for order processing, assistance, warranty maintenance, purchasing replacement parts, and other services.

\section{e. Revenue Streams}

The revenue streams of a company demonstrate where the money comes. Aircraft selling and after-sales services are the primary revenue in the CN235 aircraft business process. 


\section{f. Key Activities}

Key activities in the CN235 aircraft business process are aircraft production, sales, and marketing. In addition, the contract specifies Maintenance, Repair, and Overhaul (MRO) services of the CN235 aircraft.

\section{g. Key Resources}

Buildings, warehouses, and machinery are physical resources owned by the firm; non-physical resources owned by the firm include methods and money/capital, and human resources owned by the firm include permanent and non-permanent employees. IAe is attempting to maximize resource utilization and manage resources carefully and measurably based on advantages.

\section{h. Key Partnership}

IAe currently has collaborations both at domestic and international levels. State-owned enterprises, government ministries and institutions, and universities are domestic partnerships. As for international partners, Turkish Aerospace Industries, Airbus Group, BELL Textron, Boeing, and the Korea Aerospace Industry have established strategic partnerships with the global aviation industry.

\section{i. Cost structure}

Cost structure shows the expenses associated with operating the business. IAe cost structure divides into two categories: fixed costs and variable costs. Salary payments and corporate utilities are examples of fixed costs. Variable costs include raw materials, replacement parts, production equipment, logistics, and supply chain costs.

\section{SWOT Analysis}

After generating a current business model canvas overview, conduct an assessment by analyzing the threats and opportunities that occur in the company's environment to the company's present strengths and weaknesses, with the findings of the SWOT analysis given in the table below.

Table 2. SWOT Analysis of Business Model Canvas for Indonesian Aerospace's

CN235 Aircraft

\begin{tabular}{|c|l|l|l|l|l|}
\hline No. & \multicolumn{1}{|c|}{ Aspects } & \multicolumn{1}{|c|}{ Strengths } & \multicolumn{1}{|c|}{ Weaknesses } & Opportunities & \multicolumn{1}{|c|}{ Threats } \\
\hline 1 & $\begin{array}{l}\text { Customer } \\
\text { segments }\end{array}$ & $\begin{array}{l}\text { Domestic and } \\
\text { foreign markets }\end{array}$ & $\begin{array}{l}\text { Customer } \\
\text { preference } \\
\text { changes }\end{array}$ & $\begin{array}{l}\text { Market } \\
\text { expansion }\end{array}$ & $\begin{array}{l}\text { Similar } \\
\text { products from } \\
\text { competitors }\end{array}$ \\
\hline 2 & $\begin{array}{l}\text { Value } \\
\text { propositions }\end{array}$ & $\begin{array}{l}\text { Providing the } \\
\text { best quality, } \\
\text { price, and } \\
\text { delivery }\end{array}$ & Delay in delivery & $\begin{array}{l}\text { Demand for } \\
\text { products and } \\
\text { services has } \\
\text { increased }\end{array}$ & $\begin{array}{l}\text { Customer } \\
\text { satisfaction } \\
\text { decreased }\end{array}$ \\
\hline 3 & Channels & $\begin{array}{l}\text { Account Officer } \\
\text { in the target } \\
\text { country }\end{array}$ & $\begin{array}{l}\text { Long negotiation } \\
\text { process }\end{array}$ & $\begin{array}{l}\text { Extensive } \\
\text { marketing } \\
\text { through } \\
\text { networking }\end{array}$ & $\begin{array}{l}\text { Similar } \\
\text { products from } \\
\text { competitors }\end{array}$ \\
\hline 4 & $\begin{array}{l}\text { Customer } \\
\text { relationships }\end{array}$ & $\begin{array}{l}\text { Excellent } \\
\text { customer service }\end{array}$ & $\begin{array}{l}\text { Low domestic } \\
\text { market }\end{array}$ & $\begin{array}{l}\text { Aircraft } \\
\text { services are }\end{array}$ & $\begin{array}{l}\text { Presence of } \\
\text { local MRO }\end{array}$ \\
\hline
\end{tabular}




\begin{tabular}{|c|l|l|l|l|l|}
\hline 5 & $\begin{array}{l}\text { Revenue } \\
\text { streams }\end{array}$ & $\begin{array}{l}\text { Long-term } \\
\text { contracts }\end{array}$ & $\begin{array}{l}\text { Expenses that } \\
\text { exceed contracts }\end{array}$ & $\begin{array}{l}\text { widely needed } \\
\text { services are } \\
\text { widely needed }\end{array}$ & $\begin{array}{l}\text { Difficulty in } \\
\text { finding } \\
\text { prospective } \\
\text { consumers }\end{array}$ \\
\hline 6 & Key resources & $\begin{array}{l}\text { Reliable human } \\
\text { resources }\end{array}$ & $\begin{array}{l}\text { Outdated } \\
\text { infrastructure }\end{array}$ & $\begin{array}{l}\text { Finding for } \\
\text { alternate raw } \\
\text { materials and } \\
\text { manufacturing } \\
\text { processes }\end{array}$ & $\begin{array}{l}\text { The shortage of } \\
\text { resources and } \\
\text { raw materials }\end{array}$ \\
\hline 7 & Key activities & $\begin{array}{l}\text { SAP } \\
\text { implementation }\end{array}$ & $\begin{array}{l}\text { Outdated } \\
\text { infrastructure }\end{array}$ & $\begin{array}{l}\text { Application of } \\
\text { lean } \\
\text { manufacturing }\end{array}$ & $\begin{array}{l}\text { Global } \\
\text { technology } \\
\text { development }\end{array}$ \\
\hline 8 & $\begin{array}{l}\text { Key } \\
\text { partnerships }\end{array}$ & $\begin{array}{l}\text { Excellent } \\
\text { corporate } \\
\text { communication }\end{array}$ & Cost limitations & $\begin{array}{l}\text { International } \\
\text { and national } \\
\text { networks }\end{array}$ & $\begin{array}{l}\text { Dependency on } \\
\text { imported raw } \\
\text { resources }\end{array}$ \\
\hline 9 & Cost structure & Adequate capital & $\begin{array}{l}\text { Costs are } \\
\text { increasing }\end{array}$ & $\begin{array}{l}\text { Capability to } \\
\text { bid and choose } \\
\text { the best } \\
\text { supplier }\end{array}$ & $\begin{array}{l}\text { Material and } \\
\text { operational cost } \\
\text { increases }\end{array}$ \\
\hline
\end{tabular}

The company implemented continuous improvement strategies to deal with strengths, weaknesses, opportunities, and weaknesses. Continuous improvement is key in achieving the competitive advantage of the company. This model is based on the company's efforts to create a continuous improvement process to gain a competitive advantage and compete globally [8]. This approach is taken by technical and in all aspects of the IAe business model canvas.

\section{CONCLUSION}

The Business Model Canvas (BMC) is a visual representation of how a company creates and delivers value by collecting and evaluating the aspects that influence its business processes and impact accomplishing the goals of a company. The business process of IAe's CN235 aircraft is excellent by using the canvas business model approach. The company's existing business operations have met the nine blocks of the business idea canvas model. The SWOT analysis reveals that the organization has strengths, restrictions, opportunities, and threats in the nine business block canvas models. The company is continuously improving all aspects of IAe canvas business model.

\section{REFERENCES}

[1] A. \$Budianto, "PTDI Kuasai 25 Persen Market Share Pesawat CN235 Dunia," Sindonews, 2021. https://daerah.sindonews.com/read/369862/701/ptdi-kuasai-25persen-market-share-pesawat-cn235-dunia-1616144591 (accessed Aug. 02, 2021).

[2] R. E. Herranz, P. G. Estévez, and M. A. de Oliva, "Leveraging Financial Management Performance of the Spanish Aerospace Manufacturing Value Chain," J. Bus. Econ. Manag., vol. 18, no. 5, pp. 1005-1022, 2017. 
[3] A. Viljakainen, M. Toivonen, and M. Aikala, "Industry Transformation Towards Service Logic: A Business Model Approach,” Cambridge Serv. Alliance, vol. 1, no. 1, pp. 1-24, 2013.

[4] A. Osterwalder, Y. Pigneur, F. Etiemble, A. Smith, C. White, and T. Papadakos, The Invincible Company: Business Model Strategies From the World's Best Products, Services, and Organizations. Hoboken, N.J: John Wiley \& Sons, Inc, 2020.

[5] S. Slavik and R. Bednar, "Analysis of Business Models," J. Compet., vol. 6, no. 4, pp. 19-40, 2014, doi: 10.7441/joc.2014.04.02.

[6] B. L. Z. B. Fá and M. A. Zilber, "Innovation and Business Model: a case study about integration of Innovation Funnel and Business Model Canvas," Rev. Bus. Manag., vol. 16, no. 53, pp. 616-637, 2014, doi: 10.7819/rbgn.v16i52.1812.

[7] N. Nataliningsih and G. P. Suseno, Manajemen Strategi, no. October. Bandung: Alfabeta, 2020.

[8] S. P. Agrawal, Z. Rezaee, and H. S. Pak, "Continuous Improvement: An ActivityBased Model," Manag. Account. Q., vol. 7, no. 3, pp. 14-23, 2006. 